\title{
Assessment of allelopathic properties of Aloe ferox Mill. on turnip, beetroot and carrot
}

\author{
Sunday Arowosegbe and Anthony J. Afolayan \\ Phytomedicine Research Centre, Department of Botany, University of Fort Hare, Alice, 5700, South Africa.
}

\begin{abstract}
Turnip (Brassica rapa var. rapa L.), beetroot (Beta vulgaris L.) and carrot (Daucus carota L.) are common vegetables in South Africa. The allelopathic potential of aqueous leaf and root extracts of Aloe ferox Mill.- a highly valued medicinal plant- was evaluated against seed germination and seedling growth of the three vegetables in Petri dish experiments. The extracts were tested at concentrations of $2,4,6$ 8 , and $10 \mathrm{mg} / \mathrm{mL}$. Leaf extract concentrations above $4 \mathrm{mg} / \mathrm{mL}$ inhibited the germination of all the crops, while the root extract had no significant effect on germination irrespective of concentration. Interestingly, the lowest concentration of leaf extract stimulated root length elongation of beetroot by $31.71 \%$. Other concentrations significantly inhibited both root and shoot growth of the vegetable crops except the turnip shoot. The most sensitive crop was carrot, with percentage inhibition ranging from 29.15 to $100 \%$ for root and shoot lengths. Lower percentage inhibition was observed for the root extract than the leaf extract against shoot growth of beetroot and carrot. The results from this study suggested the presence of allelochemicals mostly in the leaves of A. ferox that could inhibit the growth of the turnip, beetroot and carrot.
\end{abstract}

Key Terms: allelopathy, Aloe ferox, aqueous extracts, intercrops, vegetable crops.

\section{INTRODUCTION}

Aloe ferox Mill., commonly called bitter or red aloe, is highly valued in South Africa for its various medicinal uses. The plant is a popular ingredient in cosmetics, herbal remedies and food supplements both locally and internationally. The processed part of A. ferox is usually taken orally as laxative or purgative and to improve digestion. It could also be applied to treat skin infections. This plant is also an income earner for South Africa through huge exportation of its products to other countries, particularly the European countries (Knapp, 2006). A. ferox (Fig. 1) is a single-stemmed seed plant that grows up to 2 or 3 metres in height. The stem, when old, is usually covered in dried leaves. The leaves are succulent and arranged in a rosette, each up to $60-100 \mathrm{~cm}$ long at maturity. The leaves have spines along the margins and sometimes on the surfaces. The flowers are carried in a large candelabra-like flower head, with about five to eight branches. Each branch carries a spikelike head of many flowers. The flower colour varies from yellow-orange to bright red, which attracts pollinating birds and insects. In South Africa, the plant grows both in the open and on mountainsides.

At present, A. ferox is readily available throughout South Africa and it is not currently listed in the Red List of Threatened Species (IUCN, 2010). However, since most of the A. ferox materials used locally and as international commercial products are harvested in the wild, the increase in demand for this plant will likely threaten the sustainability of these products. According to Gopalan (1992), overexploitation of a plant from the natural habitat could cause habitat degradation and reduction in its population. The highest priority is to conserve species in their natural habitats (in situ). To complement the in situ efforts of conserving plant biodiversity, there is a need for ex situ conservation of $A$. ferox to keep it as a sustainable crop, by bringing the plant into cultivation. For this to be successful, there is a need for the evaluation of its chemical relationships with other cultivated plants (Nandakumar, 2009), most especially as intercrops.

This chemical relationship is usually the ability of the plant to inhibit, retard or promote the germination of seeds

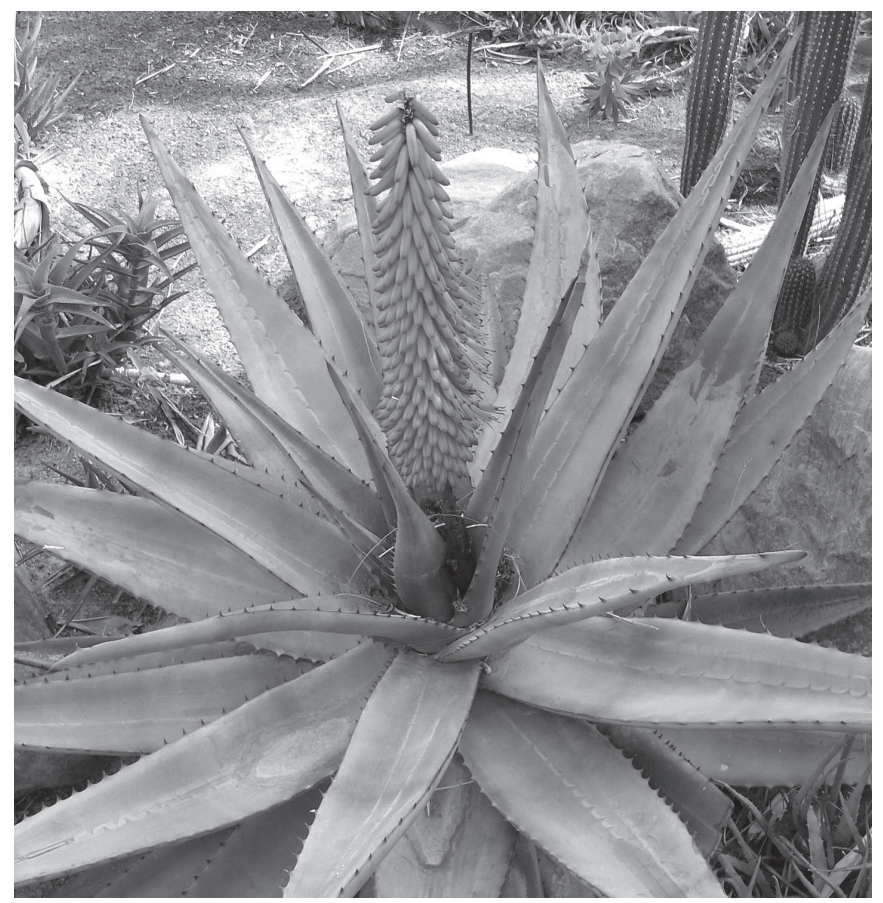

Fig.1 Aloe ferox, African Flowering Plants Database". South African National Biodiversity Institute. Retrieved 14 May 2009. 
or seedling growth of other plants through the production of allelochemicals. This phenomenon is known as allelopathy (Inderjirt, 1996; Rice, 1984). Allelochemicals may be present in any part of the plant, from where they are released to the soil in many ways (Rice, 1984; Chou 1990).

The allelopathic property of some medicinal species is of special interest in recent years. For example, Fujii et al (2003) screened 239 medicinal plants for allelopathic activity and reported that 223 species were inhibitory, while 17 species enhanced radicle growth in lettuce. Again, 11 Thai medicinal plants that were evaluated against five plant species by Piyatida and Kato-Noguchi (2010) were reported to have inhibitory effects on all the test species. Nazir et al. (2007) investigated the allelopathic potential of three medicinal species against some crops. Germination of all the crops was reduced by 2 of the 3 medicinal species. The present study was therefore carried out to investigate the allelopathic potential of aqueous leaf and root extracts of A. ferox on turnip (Brassica rapa var. rapa L.), beetroot (Beta vulgaris L.) and carrot (Daucus carota L.). The seeds were chosen as test crops because they are good representatives of crops planted as homestead crops in South Africa, supplying the community with the required vitamins, fibres and some other essential nutrients.

\section{MATERIALS AND METHODS}

Extract preparation

Fresh leaves and roots of A. ferox were collected from the field, taken to the laboratory and washed several times with tap water. Both materials were cut into small pieces, oven-dried at $500 \mathrm{C}$ for $48 \mathrm{~h}$, and pulverized using a grinder (Polymax PX-MFC 90 D, Switzerland). 100g each of the materials were soaked in 2 litres of distilled water and allowed to shake in an orbital shaker for $24 \mathrm{~h}$ at room temperature $\left(23-25{ }^{\circ} \mathrm{C}\right)$ for extraction. The extracts of the leaf and root samples were filtered using a Buchner funnel and Whatman No.1 filter paper. The filtrates were quickly frozen at $-40{ }^{\circ} \mathrm{C}$ and dried for 48 h using a freeze dryer (Savant Refrigerated Vapour Trap, RV T41404, USA) to obtain the leaf and root extract samples.

\section{Germination experiment}

Appropriate portions of the leaf and root samples were each reconstituted in $100 \mathrm{~mL}$ distilled water to give five concentration levels of 2, 4, 6, 8 and $10 \mathrm{mg} / \mathrm{mL}$, respectively. Certified seeds of turnip (Brassica rapa var. rapa), beetroot (Beta vulgaris L.) and carrot (Daucus carota L.) were purchased from a seed store in Alice, South Africa. Ten uniform and surface sterilized ( $2 \%$ sodium hypochlorite for $15 \mathrm{~min}$ ) seeds each of the three crops were placed in $9 \mathrm{~cm}$ sterilized Petri dishes lined with two Whatman No.1 filter papers. The papers were moistened with $6 \mathrm{~mL}$ of different concentrations of the aqueous extracts. Treatment in the same manner, but with distilled water, served as the control. Each treatment had three replicates maintained in a complete randomized design. The Petri dishes were kept on the germination table under laboratory conditions (room temperature $23-25{ }^{\circ} \mathrm{C}$ at mid day, and diffuse light during the day). After 7 days, seed germination counts and measurements of the root and shoot growth $(\mathrm{cm})$ of seedlings were made using the method of Abugre and Sam (2010).
Statistical analysis

The data were subjected to one way analysis of variance (ANOVA) and the mean values were separated at $\mathrm{P}<0.05$ using Duncan's Multiple Range Test. Correlations between the extract concentrations and germination, root and shoot lengths of the crops were estimated. The percentage contribution of extract concentrations to the variation observed in the studied parameters was also analysed using the coefficient of determination (R2). All statistical analyses were done using SAS software, 1999 version.

\section{RESULTS}

Effect of extracts on turnip

The aqueous leaf extract of $A$. ferox at the lowest concentration $(2 \mathrm{mg} / \mathrm{mL})$ had no significant effect on the germination of turnip (Table 1). However, concentrations above $2 \mathrm{mg} /$ $\mathrm{mL}$ significantly inhibited seed germination of the crop in a concentration dependent manner. The root extract had no significant effect on the germination of turnip irrespective of concentration.

The root length elongation of this crop at all concentrations of both the leaf and the root extracts was significantly reduced compared to the control. The percentage inhibition also increased as the concentration of the extracts increased.

The reduction in shoot length at $10 \mathrm{mg} / \mathrm{mL}$ of the extracts was not significantly different from the control. However, concentrations below this seemed to have produced a stimulatory effect on the shoot elongation of turnip, with the percentage stimulation increasing as the concentration of the extracts decreased. The correlation between the leaf extract concentrations and germination percentage and root elongation were strong and negative (Table 4). The coefficient of determination $\left(R^{2}\right)$ of the leaf extract concentrations on turnip was about 0.932 and 0.740 for germination and root length, respectively. Meanwhile, significant correlation of root extract concentrations was found only with root length, with an R2 value of 0.740 .

Effect of extracts on beetroot

Effects of A. ferox aqueous extracts on the germination of the seeds of beetroot were found to vary with the part used for the extract preparation and the concentration of the extract (Table 2). All the applied concentrations of the root extract had no significant effect on the germination of the crop. By contrast, leaf extract at 8 and $10 \mathrm{mg} / \mathrm{mL}$ caused significant inhibition in germination, by $35.01 \%$ and $50.01 \%$, respectively. However, 2 $\mathrm{mg} / \mathrm{mL}$ of the leaf extract appeared to stimulate germination of this crop, although it was not significantly different from the control.

Leaf extract at $2 \mathrm{mg} / \mathrm{mL}$ had a significant stimulatory effect on the root elongation of beetroot by $31.71 \%$. Concentrations above this however, caused a reduction in root elongation, with percentage inhibition ranging from 23.98 to $63.41 \%$. The root extract of $A$. ferox was comparatively less active than the leaf extract, with only the $10 \mathrm{mg} / \mathrm{mL}$ having significant inhibitory effect on root length elongation.

The shoot length of beetroot was significantly inhibited by the leaf extract at all concentrations; the percentage inhibition 
was between $14.63 \%$ and $45.07 \%$. This was also the same for the root extract except at $2 \mathrm{mg} / \mathrm{mL}$ with no significant difference from the control. There was significant and negative correlation between the leaf extract concentrations and all the parameters studied in beetroot (Table 4). The coefficient of determination $\left(R^{2}\right)$ of the leaf extract concentrations on beetroot was $0.686,0.678$ and 0.855 for germination, root and shoot lengths, respectively. However, root extract concentrations correlated significantly only with the shoot length of the crop, with an $\mathrm{R}^{2}$ value of 0.841 .
Effect of extracts on carrot

Carrot seemed to be the most sensitive of all the crops to $A$. ferox leaf extract (Table 3). All the concentrations significantly inhibited seed germination of carrot, with $10 \mathrm{mg} / \mathrm{mL}$ completely preventing any seed germination. The root extract had no significant effect on the germination of carrot at all concentrations. While all concentrations of the leaf extract imposed significant reduction in the root elongation of carrot, with $100 \%$ inhibition at $10 \mathrm{mg} / \mathrm{mL}$, the root extract

TABLE 1

Effect of aqueous leaf and root extracts of Aloe ferox on the germination (\%), root and shoot lengths (cm) of turnip ( $\pm \mathrm{SE})$.

\begin{tabular}{|c|c|c|c|c|c|c|}
\hline \multirow{2}{*}{$\begin{array}{c}\text { Treatments }(\mathrm{mg} / \\
\mathrm{mL})\end{array}$} & \multicolumn{3}{|c|}{ Leaf extract } & \multicolumn{3}{|c|}{ Root extract } \\
\hline & Germination & Root length & Shoot length & Germination & Root length & Shoot length \\
\hline Control & $100.00 \pm 0.00^{\mathrm{a}}$ & $6.17 \pm 0.108^{a}$ & $1.16 \pm 0.026^{\mathrm{cd}}$ & $100.00 \pm 0.00^{\mathrm{a}}$ & $6.17 \pm 0.108^{\mathrm{a}}$ & $1.16 \pm 0.026^{c}$ \\
\hline \multirow[t]{2}{*}{2} & $86.67 \pm 3.333^{a}$ & $2.45 \pm 0.044^{\mathrm{b}}$ & $2.82 \pm 0.240^{\mathrm{a}}$ & $100.00 \pm 0.00^{\mathrm{a}}$ & $2.47 \pm 0.260^{\mathrm{b}}$ & $2.27 \pm 0.020^{\mathrm{a}}$ \\
\hline & $*(-13.33)$ & $(-60.29)$ & $(+143.10)$ & (0) & $(-59.97)$ & $(+95.69)$ \\
\hline \multirow[t]{2}{*}{4} & $63.33 \pm 8.82^{b}$ & $1.12 \pm 0.079^{\mathrm{c}}$ & $2.44 \pm 0.162^{\mathrm{ab}}$ & $96.67 \pm 3.333^{a}$ & $1.39 \pm 0.110^{c}$ & $2.26 \pm 0.144^{\mathrm{a}}$ \\
\hline & $(-36.67)$ & $(-81.85)$ & $(+110.34)$ & $(-3.33)$ & $(-77.47)$ & $(+94.83)$ \\
\hline \multirow[t]{2}{*}{6} & $53.33 \pm 6.667^{\mathrm{b}}$ & $0.33 \pm 0.022^{\mathrm{d}}$ & $1.99 \pm 0.087^{\mathrm{b}}$ & $100.00 \pm 0.00^{\mathrm{a}}$ & $0.94 \pm 0.060^{\mathrm{d}}$ & $2.16 \pm 0.111^{\mathrm{a}}$ \\
\hline & $(-43.67)$ & $(-94.65)$ & $(+71.55)$ & (0) & $(-84.76)$ & $(+86.21)$ \\
\hline \multirow[t]{2}{*}{8} & $36.67 \pm 3.333^{c}$ & $0.23 \pm 0.021^{\mathrm{de}}$ & $1.44 \pm 0.239^{c}$ & $93.33 \pm 3.333^{\mathrm{a}}$ & $0.50 \pm 0.015^{\mathrm{e}}$ & $1.85 \pm 0.079^{\mathrm{b}}$ \\
\hline & $(-63.33)$ & $(-96.27)$ & $(+24.14)$ & $(-6.67)$ & $(-91.90)$ & $(+59.48)$ \\
\hline \multirow[t]{2}{*}{10} & $16.67 \pm 3.333^{\mathrm{d}}$ & $0.11 \pm 0.013^{\mathrm{e}}$ & $0.71^{\mathrm{d}}$ & $93.33 \pm 3.333^{a}$ & $0.42 \pm 0.42^{\mathrm{e}}$ & $1.13 \pm 0.120^{c}$ \\
\hline & $(-83.33)$ & $(-98.22)$ & $(-38.79)$ & $(-6.67)$ & $(-93.19)$ & $(-2.59)$ \\
\hline C.V. $(\%)$ & 12.91 & 6.31 & 14.10 & 4.47 & 10.06 & 8.45 \\
\hline
\end{tabular}

Values with the same letter within a column are not significantly different at $\mathrm{P}<0.05$ by Duncan's Multiple Range

Test (DMRT). C.V: Coefficient of Variation. *Data in brackets represent the \% inhibition (-) or stimulation (+) over control

TABLE 2

Effect of aqueous leaf and root extracts of Aloe ferox on the germination (\%), root and shoot lengths (cm) of beetroot $( \pm \mathrm{SE})$

\begin{tabular}{|c|c|c|c|c|c|c|}
\hline \multirow{2}{*}{ Treatments $(\mathrm{mg} / \mathrm{mL})$} & \multicolumn{3}{|c|}{ Leaf extract } & \multicolumn{3}{|c|}{ Root extract } \\
\hline & Germination & Root length & Shoot length & Germination & Root length & Shoot length \\
\hline Control & $66.67 \pm 3.333^{\mathrm{ab}}$ & $2.46 \pm 0.177^{\mathrm{b}}$ & $3.35 \pm 0.093^{\mathrm{a}}$ & $66.67 \pm 3.333^{\mathrm{a}}$ & $2.46 \pm 0.177^{a}$ & $3.35 \pm 0.093^{a}$ \\
\hline \multirow[t]{2}{*}{2} & $73.33 \pm 3.333^{\mathrm{a}}$ & $3.24 \pm 0.145^{\mathrm{a}}$ & $2.86 \pm 0.108^{b}$ & $66.67 \pm 3.333^{\mathrm{a}}$ & $2.49 \pm 0.173^{a}$ & $3.21 \pm 0.126^{\mathrm{a}}$ \\
\hline & *(+9.99) & $(+31.71)$ & $(-14.63)$ & $(0)$ & $(+1.22)$ & $(-4.18)$ \\
\hline \multirow[t]{2}{*}{4} & $63.33 \pm 3.333^{\mathrm{ab}}$ & $1.87 \pm 0.224^{\mathrm{c}}$ & $2.38 \pm 0.195^{c}$ & $63.33 \pm 3.333^{\mathrm{a}}$ & $2.49 \pm 0.220^{\mathrm{a}}$ & $2.70 \pm 0.128^{b}$ \\
\hline & $(-5.00)$ & $(-23.98)$ & $(-28.96)$ & $(-5.01)$ & $(+1.22)$ & $(-19.40)$ \\
\hline \multirow[t]{2}{*}{6} & $53.33 \pm 3.333^{\mathrm{bc}}$ & $1.26 \pm 0.164^{\mathrm{d}}$ & $2.26 \pm 0.080^{\mathrm{cd}}$ & $66.37 \pm 8.819^{a}$ & $2.43 \pm 0.066^{\mathrm{a}}$ & $2.62 \pm 0.132^{b}$ \\
\hline & $(-20.00)$ & $(-48.78)$ & $(-32.54)$ & $(-0.45)$ & $(-1.22)$ & $(-21.79)$ \\
\hline \multirow[t]{2}{*}{8} & $43.33 \pm 6.667^{\mathrm{cd}}$ & $1.11 \pm 0.144^{\mathrm{d}}$ & $2.04 \pm 0.037^{\mathrm{de}}$ & $63.33 \pm 6.667^{\mathrm{a}}$ & $2.41 \pm 0.134^{\mathrm{a}}$ & $2.40 \pm 0.048^{\mathrm{bc}}$ \\
\hline & $(-35.01)$ & $(-54.88)$ & $(-39.10)$ & $(-5.01)$ & $(-2.03)$ & $(-28.36)$ \\
\hline \multirow[t]{2}{*}{10} & $33.33 \pm 8.819^{d}$ & $0.90 \pm 0.153^{d}$ & $1.84 \pm 0.117^{\mathrm{e}}$ & $70.00 \pm 0.000^{\mathrm{a}}$ & $1.26 \pm 0.058^{\mathrm{b}}$ & $2.2 \pm 0.038^{c}$ \\
\hline & $(-50.01)$ & $(-63.41)$ & $(-45.07)$ & $(+4.99)$ & $(-48.78)$ & $(-32.84)$ \\
\hline C.V. $(\%)$ & 14.57 & 16.65 & 6.54 & 14.26 & 10.66 & 5.91 \\
\hline
\end{tabular}

Values with the same letter within a column are not significantly different at $\mathrm{P}<0.05$ by Duncan's Multiple Range

Test (DMRT). C.V: Coefficient of Variation. *Data in brackets represent the \% inhibition (-) or stimulation (+) over control 
only at 8 and $10 \mathrm{mg} / \mathrm{mL}$ had significant inhibitory effect The same trend was observed in the response of shoot length to the leaf extract (Table 3). All root extract concentrations except $2 \mathrm{mg} / \mathrm{mL}$ also inhibited shoot elongation of this crop. However, the percentage inhibition on both the root and shoot elongation were small compared to the effects caused by the leaf extract. Negative significant correlations were observed between the leaf and the root extract concentrations and all the studied parameters in carrot except germination (Table $4)$. The coefficients of determination $\left(R^{2}\right)$ of the leaf extract concentrations on carrot were $0.926,0.815$ and 0.950 for germination, root and shoot lengths, respectively, while the R2 value of the root extract concentrations was 0.715 and 0.829 for root and shoot lengths, respectively.

\section{DISCUSSION}

The results of this study demonstrated that extracts from Aloe ferox plant contain indeed some phytochemicals capable of affecting germination and seedling growth of the tested vegetable crops. The extent of the effect of the phytochemicals seemed to be dependent on the part of the plant used for the extract preparation, the concentration of the extracts as well as the target vegetable crop involved. Leaf extracts

TABLE 3

Effect of aqueous leaf and root extracts of Aloe ferox on the germination (\%), root and shoot lengths (cm) of carrot $( \pm \mathrm{SE})$

\begin{tabular}{|c|c|c|c|c|c|c|}
\hline \multirow{2}{*}{ Treatments $(\mathrm{mg} / \mathrm{mL})$} & \multicolumn{3}{|c|}{ Leaf extract } & \multicolumn{3}{|c|}{ Root extract } \\
\hline & Germination & Root length & Shoot length & Germination & Root length & Shoot length \\
\hline Control & $96.67 \pm 3.333^{\mathrm{a}}$ & $2.56 \pm 0.096^{\mathrm{a}}$ & $2.47 \pm 0.104^{\mathrm{a}}$ & $96.67 \pm 3.333^{a}$ & $2.56 \pm 0.096^{\mathrm{a}}$ & $2.47 \pm 0.104^{\mathrm{a}}$ \\
\hline \multirow[t]{2}{*}{2} & $80.00 \pm 0.000^{\mathrm{b}}$ & $1.56 \pm 0.047^{\mathrm{b}}$ & $1.75 \pm 0.135^{\mathrm{b}}$ & $90.00 \pm 5.773^{a}$ & $2.54 \pm 0.083^{\mathrm{a}}$ & $2.39 \pm 0.112^{\mathrm{ab}}$ \\
\hline & $*(-17.24)$ & $(-39.06)$ & $(-29.15)$ & $(-6.90)$ & $(-0.78)$ & $(-3.24)$ \\
\hline \multirow[t]{2}{*}{4} & $66.67 \pm 6.667^{b}$ & $0.76 \pm 0.123^{c}$ & $1.09 \pm 0.107^{c}$ & $86.67 \pm 6.667^{\mathrm{a}}$ & $2.44 \pm 0.116^{\mathrm{a}}$ & $2.18 \pm 0.046 b^{c}$ \\
\hline & $(-31.03)$ & $(-70.31)$ & $(-55.87)$ & $(-10.34)$ & $(-4.69)$ & $(-11.74)$ \\
\hline \multirow[t]{2}{*}{6} & $23.33 \pm 6.667^{c}$ & $0.92 \pm 0.039^{c}$ & $0.80 \pm 0.087^{c}$ & $93.33 \pm 3.333^{a}$ & $2.32 \pm 0.032^{\mathrm{ab}}$ & $2.03 \pm 0.074^{\mathrm{c}}$ \\
\hline & $(-75.87)$ & $(-64.06)$ & $(-67.61)$ & $(-3.46)$ & $(-9.38)$ & $(-17.81)$ \\
\hline \multirow[t]{2}{*}{8} & $20.00 \pm 5.773^{c}$ & $0.85 \pm 0.047^{\mathrm{c}}$ & $0.42 \pm 0.027^{\mathrm{d}}$ & $90.00 \pm 5.773^{a}$ & $2.05 \pm 0.110^{\mathrm{b}}$ & $1.93 \pm 0.056^{\mathrm{cd}}$ \\
\hline & $(-79.31)$ & $(-66.80)$ & $(-83.00)$ & $(-6.90)$ & $(-19.92)$ & $(-21.86)$ \\
\hline \multirow[t]{2}{*}{10} & $0.00 \pm 0.000^{\mathrm{d}}$ & $0.00 \pm 0.000^{\mathrm{d}}$ & $0.00 \pm 0.000^{\mathrm{e}}$ & $86.67 \pm 6.667^{a}$ & $1.65 \pm 0.159^{c}$ & $1.74 \pm 0.059^{\mathrm{d}}$ \\
\hline & $(-100.00)$ & $(-100.00)$ & $(-100.00)$ & $(-10.34)$ & $(-35.55)$ & $(-29.55)$ \\
\hline C.V.(\%) & 16.06 & 7.99 & 15.64 & 11.35 & 8.49 & 7.00 \\
\hline
\end{tabular}

Values with the same letter within a column are not significantly different at $\mathrm{P}<0.05$ by Duncan's Multiple Range

Test (DMRT). C.V: Coefficient of Variation. *Data in brackets represent the \% inhibition (-) or stimulation (+) over control

TABLE 4

Correlation coefficient and Coefficient of determination $\left(\mathrm{R}^{2}\right)$ between extract concentrations and studied parameters of the test vegetable crops

\begin{tabular}{|c|c|c|c|c|c|}
\hline \multirow[b]{3}{*}{ Test crops } & \multirow[b]{3}{*}{ Parameters } & \multicolumn{2}{|c|}{ Plant extracts } & & \\
\hline & & \multicolumn{2}{|c|}{ Correlation Coefficient } & \multicolumn{2}{|c|}{$\mathrm{R}^{2}$} \\
\hline & & Leaf & Root & Leaf & Root \\
\hline \multirow[t]{3}{*}{ Turnip } & germination & $-0.965^{\star *}$ & - 0.545NS & 0.932 & 0.297 \\
\hline & root length & $-0.860^{\star *}$ & $-0.856^{* *}$ & 0.740 & 0.740 \\
\hline & shoot length & $-0.436 \mathrm{NS}$ & $-0.144 \mathrm{NS}$ & 0.190 & 0.021 \\
\hline \multirow[t]{3}{*}{ Beetroot } & germination & $-0.828^{* *}$ & $0.065 \mathrm{NS}$ & 0.686 & 0.004 \\
\hline & root length & $-0.824^{* *}$ & - 0.623NS & 0.678 & 0.388 \\
\hline & shoot length & $-0.925^{\star *}$ & $-0.917^{* *}$ & 0.855 & 0.841 \\
\hline \multirow[t]{3}{*}{ Carrot } & germination & $-0.962^{* *}$ & $-0.249 \mathrm{NS}$ & 0.926 & 0.062 \\
\hline & root length & $-0.903^{* *}$ & $-0.845^{\star *}$ & 0.815 & 0.715 \\
\hline & shoot length & $-0.975^{* *}$ & $-0.910^{* *}$ & 0.950 & 0.829 \\
\hline
\end{tabular}

NS: No significant difference at $\mathrm{P}<0.05$; ${ }^{*}$ significant difference at $\mathrm{P}<0.01$ level of probability. 
were found to have more inhibitory property than the root extracts. For instance, leaf extract of $A$. ferox above $4 \mathrm{mg} / \mathrm{mL}$ exhibited significant inhibitory effects on seed germination of all the vegetable crops studied, whereas no significant inhibitory effect was recorded for root extract on germination of the crops. Similarly, stronger inhibitory allelopathic effects of leaf extract than root extract of A. ferox was observed in the elongation of root and shoot lengths of beetroot and carrot.

The observed stronger allelopathic impact of leaf extracts than root extracts on the tested vegetable crops might be connected with the presence of higher concentrations of allelochemicals such as tannins, alkaloids and flavonoids in the leaves than in the roots (Kanchan and Jayachandra, 1980). Different tissues of plants (leaves, stems and roots) are capable of releasing different amounts of allelochemicals into the surrounding environment (Scrivanti, 2010), thereby inflicting different effects on other plants in that vicinity. Stronger inhibitory potential of leaf extracts than other vegetative parts was also reported for some other plants like Parthenium hysterophorus (Tefera, 2002; Maharjan et al., 2007) and Croton bonplandianum (Sisodia and Siddiqui, 2010).

The results of this study also indicated that the inhibitory effects of the extracts on germination, root and shoot growth of the three crops, in most cases increased as the extract concentration increased, and hence were concentration dependent. Maharjan et al. (2007) reported that high concentrations of aqueous leaf extract of Parthenium hysterophorus also had strong inhibitory effect on the germination of some cultivated and wild herbaceous plant species. In all extracts of sunflower, allelopathicity was also found to increase with increase in concentrations (Ashrafi et al., 2008). The negative but significant correlation observed between the extract concentrations and most of the parameters of the target crops in this study further confirmed that the effect of $A$. ferox extracts on the germination and seedling growth of these crops is concentration dependent. Singh et al. (2005) also found a strong positive correlation between extract concentrations of residues of Parthenium hysterophorus and reduction in seedling length of Brassica species. (i.e. extract concentration negatively correlated with increase in seedling length). About $74.03 \%$ of the variation observed in the root length of turnip seedlings as a result of application of A. ferox leaf extract could be attributed to differences in the concentration of the extract, as indicated by the $R^{2}$ value of 0.740. Moreover, differences in the extract concentrations contributed between $67.80-85.20 \%\left(R^{2} ; 0.678-0.852\right)$ and 81.50 - $95.00\left(R^{2} ; 0.0815-0.950\right)$ to the effects of the leaf extract on the germination, root and shoot lengths of beetroot and carrot, respectively.

The $100 \%$ inhibition of seed germination, root and shoot elongation of carrot by the $10 \mathrm{mg} / \mathrm{mL}$ leaf extract of $A$. ferox could occur only when some allelochemicals present in the leaves prevented growth of the embryo or caused complete death of the cells. The allelochemicals might have also prevented water uptake (Tawaha and Turk, 2003), or caused an alteration in the synthesis or activation of gibberelic acid (Olofsdotter, 2001), a growth promoting hormone.

It was also observed in this study that there were stronger inhibitory effects of extracts on seedling roots than the shoots of the tested crops in most cases. The difference in the sensitivity might be due to the fact that roots were in direct contact with the extract and subsequently with inhibitory chemicals, as described in earlier studies on some other plant species (Bhowmik and Doll, 1984; Quasem, 1995; Tefera,

2002). According to Chon et al. (2000), root length was the best indicator of allelopathic effects of plant extracts due to its higher sensitivity to phytotoxic compounds than the hypocotyls. Root tissue was also reported to be more permeable to allelochemicals than shoot tissue (Nishida et al., 2005). The difference in the genetic makeup of the target vegetable crops is likely to be responsible for the differential responses to the extract treatments, with carrot being the most sensitive crop.

Aqueous extracts of A. ferox exhibited allelopathic activity on the three vegetables, with the greatest effect on carrot. The leaf extract of the plant had more inhibitory effect than the root extract. Whereas the lowest concentration of leaf extract $(2 \mathrm{mg} / \mathrm{mL}$ ) stimulated root growth of beetroot, leaf extract concentrations above $4 \mathrm{mg} / \mathrm{mL}$ generally inhibited seedling growth of the vegetable crops investigated in a concentration dependent manner. At present, A. ferox is not vulnerable in the wild; however, there is concern that continuous harvesting from the wild could lead to local extinction (Van Wyk and Smith, 1996). The results of this study could be a way forward to the assertion of Pfab and Scholes (2004) that sustainability of plants harvested from the wild can never be achieved without ex situ cultivation. Even though the effects obtained under laboratory conditions may not always be what are obtained in the field, it can be concluded that A. ferox is better planted as a sole crop since it could affect crops like carrot, beetroot and turnip as intercrops.

\section{ACKNOWLEDGEMENTS}

The authors are grateful to the Govan Mbeki Research and Development Centre, University of Fort Hare, Alice, South Africa for their financial support.

\section{REFERENCES}

ABUGRE S, SAM SJQ (2010) Evaluating the allelopathic effect of Jatropha curcus aqueous extract on germinat ion, radicle and plumule length of crops. Int J Agric Biol 12: 769-772.

ASHRAFI ZY, SADEGHI S, MASHHADI HR, HASSAN MA (2008) Allelopathic effects of sunflower (Helianthus annuus) on germination and growth of wild barley (Hordeum spontaneum). J Agri Tech 4: 219-229.

BHOWMIK PC, DOLL JD (1984) Allelopathic effects of annual weed residues on growth and nutrient uptake of corn and soybean. Agron J 76: 383 -388 .

CHON SU, COUTTS JH, NELSON CJ (2000) Effects of light, growth media and seedling orientation on bioassays of alfalfa autotoxicity. Agron. J 92: 715-720.

CHOU CH (1990) The role of allelopathy in agro ecosystem studies from tropical Taiwan. Ecol Stud 78: 105-121.

FUJII Y, PARVES SS, PARVEZ MM, OHMAE Y, IIDA O (2003) Screening of 239 medicinal plant species for allelopathic activity using Sandwich methods. Weed Bio \& Manag 3: 233-241.

GOPALAN, C (1992) New dimensions of old problems. In: Nutrition in development transition in Southeast Asia. World Health Organisation. Regional office for Southeast Asia, New Delhi. pp: 34-48.

INDERJIRT L (1996) Plant phenolics in allelopathy. Bot Rev 62: 186-202

INTERNATIONAL UNION FOR CONSERVATION OF NATURE (IUCN) (2010) IUCN Red List of Threatened Species. Version 2010.4. < www. iucnredlist.org > download on 27 January 2011.

KANCHAN SD, JAYACHANDRA (1980) Allelopathic effects of Parthenium hysterophorus L. IV. Identificat ion of inhibitors. Plant and Soil 55: 67-75.

KNAPP A (2006) A review of the trade in Aloe ferox with a focus on the role of European Commission. A TRAFFIC Europe Report Commission, Brussels, Belgium. pp: 1-28. 
MAHARJAN S, SHRESTHA BB, JHA PK (2007) Allelopathic effects of aqueous extract of leaves of Parthenium hysterphorus L. on seed germination and seedling growth of some cultivated and wild herbaceous species. Sc World., 5(5): 33-39.

NANDAKUMAR J (2009) Ex situ Conservation of medicinal plants in Valikamam area of Jaffna Penisula, Sri Lanka. New Biot J 25: 370.

NAZIR T, UNIYAL AK, TODARIA NP (2007) Allelopathic behaviour of three medicinal plant species on traditional agriculture crops of Garhwal Hamalaya, India. Agroforest syst 69: 183-187.

NISHIDA N, TAMOTSU S, NAGATA N, SAITO C, SAKAI A (2005) Allelopathic effects of volatile monoterpenoids produced by Salvia leucophylla: Inhibition of cell proliferation and DNA synt hesis in the root apical meristem of Brassica campestris seedlings. J Chem Ecol 31: 1187-1203.

OLOFSDOTTER M (2001) Rice - A Step toward use of allelopathy. Agron J 93: 3-8.

PFAB MF, SCHOLES MA (2004) Is the collection of Aloe peglerae from the wild sustainable? An evaluation using Stochastic population modelling. Biol Conserv 118: 695-701.

PIYATIDA P, KATO-NOGUCHI H (2010) Screening of allelopathic activity of eleven Thai medicinal plants on seedling growth of five test plant species. Asian J Pla Sci 9(8): 486-491.
QUASEM JR (1995) The allelopathic effect of three Amaranthus spp. (Pigweeds) on wheat (Triticum durum). Weed Res 35: 41-49.

RICE EL (1984) Allelopathy. 2nd edition. Academic Press Inc. Florida, USA. SAS (1999) Proprietary software release 8.2. SAS institute Inc. NC, USA.

SCRIVANTI LR (2010) Allelopathic potential of Bothriochloe laguroides var laguroides (DC.) Herter (Poaceae: Andropogoneae). Flora.205: 302-305.

SINGH HP, BATISH DR, PANDHER JK, KOHIL RK (2005) Phytotoxic effects of Parthenium hysterophorus residues on three Brassica species. Weed Biol Manag 5(3): 105-109.

SISODIA A, SIDDIQUI MB (2010) Allelopathic effects of aqueous extracts of different parts of Croton bonplandianum Bill. On some crops and weed plants. J Agric Ext \& Rur Dev 2(1): 022-028.

TAWAHA AM, TURK MA (2003) Allelopathic effects of black musard (Brassica nigra) on germination and growth of wild barley (Hordeum spontanenm). J Agron Crop Sci 189: 298-303.

TEFERA T (2002) Allelopathic effects of Parthenium hysterphorus extracts on seed germination and seedling growth of Eragrostis tef (zucc.) Trotter. J Agron Crop Sci 188(5): 306-310.

VAN WYK BE, SMITH G (1996) Guide to the Aloes of South Africa. Briza Publications, Pretoria, South Africa. 